\title{
Effect of Saccharomyces cerevisiae Supplementation on Some Serum Electrolytes of Weaned Rabbits
}

\author{
B. M. Shehu ${ }^{1,2}$, B. A. Ayanwale ${ }^{3}$ J. O. $A_{y o}^{4}$, J. T. Amodu ${ }^{5} \&$ A. T. Ijaiya ${ }^{3}$ \\ ${ }^{1}$ Department of Agricultural Leadership, Education, and Communication, University of Nebraska-Lincoln, USA \\ ${ }^{2}$ National Agricultural Extension and Research Liaison Service, Ahmadu Bello University, Zaria, Nigeria \\ ${ }^{3}$ Department of Animal Production, Federal University of Technology, Minna, Nigeria \\ ${ }^{4}$ Department of Veterinary Physiology and Pharmacology, Ahmadu Bello University, Zaria, Nigeria \\ ${ }^{5}$ National Animal Production Research Institute, Ahmadu Bello University, Zaria, Nigeria \\ Correspondence: B. M. Shehu, Department of Agricultural Leadership, Education, and Communication, \\ University of Nebraska-Lincoln, 300 Agricultural Hall Lincoln, NE 68583-0709, USA. Tel: 1-312-714-6504. \\ E-mail: bala.shehu@unl.edu
}

Received: October 20, 2014 Accepted: January 11, 2015 Online Published: February 15, 2015

doi:10.5539/jas.v7n3p206 URL: http://dx.doi.org/10.5539/jas.v7n3p206

\begin{abstract}
A feeding trial was conducted to evaluate the effect of Saccharomyces cerevisiae (SC) supplementation on some serum electrolytes in rabbits. Sixty (60) weaned crossbred rabbits aged between 5-6 weeks, with live weight of $612.73 \pm 60.84 \mathrm{~g}$ were used in this study. A total of 60 rabbits were divided into five treatment groups: TRT1 receiving control diet- without supplementation of SC, and TRT2, TRT3, TRT4 and TRT5 receiving the control diet supplemented with SC at the rate of 20, 40, 60 and $80 \mathrm{~g}$ per $\mathrm{kg}$ for 8 weeks (corresponding to 2, 4, 6 and $8 \times$ $10^{9}$ colony-forming unit $/ \mathrm{kg}$, respectively). The concentrations of Sodium $\left(\mathrm{Na}^{+}\right)$, Potassium $\left(\mathrm{K}^{+}\right)$and Bicarbonate $\left(\mathrm{HCO}_{3}{ }^{-}\right)$in serum were not affected, but Chloride $\left(\mathrm{Cl}^{-}\right)$concentration rose $(\mathrm{P}<0.05)$ as the SC inclusion level increased. Although further studies are required, baker's yeast containing SC could contribute to stabilizing the mineral balance in rabbits.
\end{abstract}

Keywords: Saccharomyces cerevisiae, serum electrolytes, rabbits

\section{Introduction}

Increasing demand for animal protein and the economic hardship faced by the populace in the tropics have stimulated greater interest in fast-growing animals with short generation intervals such as the rabbit (Aduku \& Olukosi, 1990). Low level of antibiotics has over the years been used in rabbit production as growth promoters and prophylactic agents of diseases (Falcão-e-Cunha et al., 2007). However, the massive use of antibiotics for disease prevention and growth promotion in animal production has been implicated in the emergence of antibiotic-resistant pathogens and antibiotic residues in animal products, which is a public health concern. Constraints on the use of antibiotics in animal nutrition globally require alternative feed additives to antibiotics for improved growth performance, sound physiological status and productivity. The alternative feed additives are required to meet consumer demands for natural products and maintain high standards of wholesomeness expected in rabbit meat. One of such alternatives is Saccharomyces cerevisiae (SC), demonstrated to be a valuable and qualitative supplement for feeding livestock (Falcão-e-Cunha et al., 2007; Shareef \& AL-Dabbagh, 2009). Changes in blood composition, when compared to normal values are of value in the interpretation of the metabolic stage of an animal and feed quality (Babatunde et al., 1992). Electrolytes are positively and negatively charged molecules, which are found within the body's cells and fluids, including blood serum. Sodium ( $\left.\mathrm{Na}^{+}\right)$, Potassium $\left(\mathrm{K}^{+}\right)$, Chloride $\left(\mathrm{Cl}^{-}\right)$, and bicarbonate $\left(\mathrm{HCO}_{3}{ }^{-}\right)$are important electrolytes used to assess comprehensive metabolic profiles of livestock (Ingraham \& Kappel (1988). Therefore, the present study was undertaken to investigate the effect of varying levels of baker's yeast, SC supplementation on some serum electrolytes of weaned rabbits in the Northern Guinea Savannah zone of Nigeria. 


\section{Materials and Methods}

\subsection{Study Area}

The study was conducted at the Rabbitry Unit of the Skill Acquisition and Development Centre of the National Agricultural Extension and Research Liaison Services, Ahmadu Bello University, Zaria $\left(11^{\circ} 12^{\prime} \mathrm{N}, 07^{\circ} 33^{\prime} \mathrm{E}\right)$, located in the Northern Guinea Savannah zone of Nigeria.

\subsection{Experimental Animals and Their Management}

Sixty (60) weaned crossbred rabbits in equal sexes, aged between 5-6 weeks with initial live weight of $612.73 \pm$ $60.84 \mathrm{~g}$ (mean \pm standard deviation) were procured from Samaru market in Zaria, Kaduna State. Prior to the commencement of the experiment, the rabbits were pre-conditioned for two weeks, during which they were treated twice (once per week) against parasitic infestation with Ivermectin (Laboratorios Calier, Barcelona, Spain) at the dose rate of $0.1 \mathrm{ml}$ per rabbit. The rabbits were housed in a well-ventilated in three- tier-wire cages. Each cage measured $70 \times 60 \times 50 \mathrm{~cm}$ in length, width and height, respectively. The wire cages were fitted with earthen drinkers and feeders, and aluminium tray for collection of faeces and urine.

\subsection{Experimental Diets}

A Commercial Baker's yeast, containing SC was used for the dietary supplementation. The rabbits were divided into five treatment groups: TRT1 Control diet without supplementation of SC, and TRT2, TRT3, TRT4 and TRT5 diets supplemented with SC at the rate of 20, 40, 60 and $80 \mathrm{~g} \mathrm{~kg}^{-1}$ for 8 weeks (corresponding to 2, 4, 6 and $8 \times$ $10^{9}$ colony-forming unit $/ \mathrm{kg}$, respectively). The diets were not pelleted. Analyzed proximate composition of the basal diet according to the Procedures of Association of Official Analytical Chemists (AOAC, 2000), showed that it contained $16.02 \%$ crude protein, $14.11 \%$ crude fibre, $3.91 \%$ ether extract, $10.21 \%$ ash and $2607.80 \mathrm{kcal}$ $\mathrm{ME} / \mathrm{kg}$ feed. The experimental animals were offered fresh water ad libitum during the feeding trial.

Table 1. Ingredients and nutritional composition of basal diet

\begin{tabular}{ll}
\hline Items & \\
\hline Ingredients (\%) & 25 \\
Maize & 5 \\
Soybean meal & 15 \\
Maize offal & 25 \\
Brewer's dried grain & 2 \\
Blood meal & 12 \\
Groundnut cake & 12 \\
Rice offal & 3 \\
Bone meal & 0.25 \\
Salt & 0.25 \\
Premix & \\
Lysine & 0.25 \\
Methionine & 0.25 \\
Total & 100 \\
Nutrient composition & \\
Dry matter (\%) & 94.63 \\
Crude protein (\% DM) & 16.02 \\
Crude fibre (\% DM) & 14.11 \\
Ether extract (\% DM) & 3.91 \\
Ash (\% DM) & 10.21 \\
Nitrogen free extract (\% DM) & 50.38 \\
Metabolizable energy (Kcal/kg) & 2607.80 \\
\hline Dratter. & \\
\hline
\end{tabular}

Note. $\mathrm{DM}=\overline{\text { Dry matter. }}$

${ }^{\text {a}}$ Provided per kilogram of diet: vitamin A, $10000 \mathrm{IU}$ (retinyl acetate); cholecalciferol, $3000 \mathrm{IU}$; vitamin E, 8.0 IU (DL-a-tocopheryl acetate); K, $2.0 \mathrm{mg}$; thiamine, $2.0 \mathrm{mg}$; pyridoxine, $1.2 \mathrm{mg}$; cyanocobalamin, $0.12 \mathrm{mg}$; niacin, $1.0 \mathrm{mg}$; pantothenic acid, $7.0 \mathrm{mg}$; folic acid, $0.6 \mathrm{mg}$; choline chloride, $500 \mathrm{mg}$; Fe, $60 \mathrm{mg}$; $\mathrm{Mn}, 100 \mathrm{mg}$; $\mathrm{Cu}, 8.0 \mathrm{mg} ; \mathrm{Zn}, 50 \mathrm{mg}$; Co, $0.45 \mathrm{mg}$; I, $2.0 \mathrm{mg}$; Se, $0.1 \mathrm{mg}$. 


\subsection{Experimental Procedures}

The sixty rabbits were randomly allocated into five treatment groups of 12 animals per treatment, after balancing for live weight. The five treatment groups were allotted to the five experimental diets in a completely randomized design (CRD). Each treatment with 12 rabbits was divided into three replicates, each comprising four rabbits. The experiment lasted for 8 weeks (56 days).

\subsection{Blood Sample Collection and Serum Evaluation of Electrolytes}

At the end of the feeding period, 6 rabbits from each treatment (two from each replicate) were starved overnight of feed for $12 \mathrm{~h}$ before blood samples were collected. Blood sample $(3 \mathrm{ml})$ was collected aseptically from each rabbit from the marginal vein of the ear using a sterilised disposable syringe and needle between 06:30 and 07:30 a.m. The blood sample was transferred into a centrifuge tube, allowed to clot and then incubated for 30 mins, thereafter centrifuged at $2000 \mathrm{~g}$ for $10 \mathrm{~min}$ in a microcentrifuge to obtain serum. The sera samples collected were used to determine the concentration of $\mathrm{Na}^{+}, \mathrm{K}^{+}, \mathrm{Cl}^{-}$, and $\mathrm{HCO}_{3}{ }^{-}$. Serum electrolyte concentrations were determined using Flame Photometry Method (Dacie \& Lewis, 1991).

\subsection{Statistical Analysis}

The data obtained were subjected to one-way ANOVA test in a completely randomized design using SAS 9.1 software package (SAS Institute, 2004), with the type of diet SC level serving as the main source of variation. The means were compared using Duncan's New Multiple Range Test (Duncan, 1955). Polynomial orthogonal contrasts (linear, quadratic, cubic and quartic) were applied to determine the effects of different supplemental levels $(0,20,40,60$ and $80 \mathrm{~g} / \mathrm{kg})$ of $\mathrm{SC}$. Values of $\mathrm{P} \leq 0.05$ were considered significant

\section{Results}

The serum electrolyte concentrations of weaned rabbits fed diets supplemented with varying levels of SC are shown in Table 2. The levels of $\mathrm{Na}^{+}, \mathrm{K}^{+}$and $\mathrm{HCO}_{3}{ }^{-}$in serum were not affected, but $\mathrm{Cl}^{-}$concentration rose $(\mathrm{P}<$ $0.05)$ as the $\mathrm{SC}$ inclusion level increased. There was a comparative increase in the levels of $\mathrm{Na}^{+}$(linear trend), $\mathrm{K}^{+}$ (no trend), $\mathrm{HCO}_{3}^{-}$(no trend) and $\mathrm{Cl}^{-}$(linear and quadratic trend) with increase in the levels of SC in the diets. The highest serum concentrations of $\mathrm{Na}^{+}(141.17 \mathrm{mmol} / \mathrm{l}), \mathrm{K}^{+}(4.58 \mathrm{mmol} / \mathrm{l}), \mathrm{Cl}^{-}(123.83 \mathrm{mmol} / \mathrm{l})$, and $\mathrm{HCO}_{3}$ $(22.67 \mathrm{mmol} / \mathrm{l})$ were observed in rabbits fed diet supplemented with SC at $80 \mathrm{~g} / \mathrm{kg}$ of basal diet.

\section{Discussion}

The result demonstrated that yeast supplementation caused no significant $(\mathrm{P}>0.05)$ increase in the serum levels of $\mathrm{Na}^{+}, \mathrm{K}^{+}$, and $\mathrm{HCO}_{3}{ }_{3}$, but significantly increased the levels of $\mathrm{Cl}^{-}$concentration (Table 2). The levels of $\mathrm{Na}^{+}, \mathrm{K}^{+}$, $\mathrm{HCO}_{3}$ and $\mathrm{Cl}^{-}$obtained in the present study are within the normal physiological values (Favarato \& Zatta, 1990). SC supplementation, apparently, stabilized the normal mineral balance in rabbits.

Table 2. Serum electrolytes concentrations of weaned rabbits fed varying levels of SC-supplemented diets

\begin{tabular}{llllllll}
\hline \multicolumn{7}{c}{ SC g/kg of basal diet } \\
\hline $\begin{array}{l}\text { Electrolyte } \\
(\mathrm{mmol} / \mathrm{l})\end{array}$ & 0 & 20 & 40 & 60 & 80 & LOS & $\begin{array}{l}\text { SC inclusion level } \\
\text { trend }\end{array}$ \\
\hline $\mathrm{Na}^{+}$ & $137.17 \pm 1.62$ & $138.50 \pm 0.76$ & $140.83 \pm 0.91$ & $141.00 \pm 1.07$ & $141.17 \pm 1.17$ & NS & Linear \\
$\mathrm{K}^{+}$ & $4.38 \pm 0.09$ & $4.40 \pm 0.13$ & $4.43 \pm 0.18$ & $4.52 \pm 0.10$ & $4.58 \pm 0.10$ & NS & NT \\
$\mathrm{Cl}^{-}$ & $104.67 \pm 1.93^{\mathrm{b}}$ & $105.33 \pm 2.272^{\mathrm{b}}$ & $106.33 \pm 2.81^{\mathrm{b}}$ & $107.00 \pm 1.24^{\mathrm{b}}$ & $123.83 \pm 7.06^{\mathrm{a}}$ & 0.0024 & Linear and Quadratic \\
$\mathrm{HCO}_{3}{ }^{-}$ & $20.83 \pm 0.83$ & $21.33 \pm 1.12$ & $21.17 \pm 0.98$ & $22.67 \pm 1.12$ & $22.67 \pm 0.99$ & NS & NT \\
\hline
\end{tabular}

Note. $0 \mathrm{~g}=$ TRT1 (Control), $20 \mathrm{~g}=\mathrm{TRT} 2,40 \mathrm{~g}=\mathrm{TRT} 3,60 \mathrm{~g}=\mathrm{TRT} 4,80 \mathrm{~g}=\mathrm{TRT} 5$; $\mathrm{SC}=$ Saccharomyces cerevisiae, $\mathrm{LOS}=$ Level of significance, $\mathrm{NS}=$ Not significant, $\mathrm{NT}=$ No trend; ${ }^{\mathrm{ab}}=$ Means in the same row with different superscript letters are significantly $(\mathrm{P}<0.05)$ different.

Therefore, dietary yeast may be able to enhance the activities of hormones, involved in the maintenance of normal mineral balance. The finding of the present study agrees with the results obtained by Hassan et al. (2011), who reported that the normal mineral balance participates in improving the growth performance and immune response New Zealand White rabbits, supplemented with betane. Yeast supplementation also improved the growth performance of rabbits in a study by Shehu et al. (2014). 
The slight insignificant increase in $\mathrm{HCO}_{3}{ }^{-}$concentrations in the $\mathrm{SC}$ supplemented groups shows the protective role played by SC in water and electrolyte loss as reported by Rodrigues et al. (1996). The authors explained that SC reduced the amount of available toxins, secreted by pathogens and compete for adhesion sites in the gastro-intestinal tract, which helps in water and electrolyte retention. Numerous research studies have shown that yeast significantly affects the gastro-intestinal tract environment and the acid-base balance in blood due to the stimulating effect of yeast on the synthesis of short-chain fatty acids, accompanied by diminished production of lactic acid (Galip, 2006) and (Stanislaw et al., 2009).

\section{Conclusion}

The present study has revealed that supplementation of weaner rabbit diets with baker's yeast containing SC could contribute to stabilizing the normal mineral balance in rabbits raised in the Northern Guinea Savannah zone of Nigeria as shown by the concentration of serum electrolytes studied.

\section{References}

Aduku, A. O., \& Olukosi, J. O. (1990). Rabbit Management in the Tropics: Production, Processing, Utilization, Marketing, Economics, Research and Future Prospects. Abuja: Living Books Series.

Association of Official Analytical Chemists (AOAC). (2000). Official Methods of Analysis (16th ed.). Washington, D.C., Association of Official Analytical Chemists.

Babatunde, G. M., Fajimi, A. O., \& Oyejide, A. O. (1992). Rubber seed oil versus palm oil in broiler chicken diets. Effects on performance, nutrient digestibility, haematology and carcass characteristics. Animal Feed Science Technology, 35, 133-146.

Dacie, J. V., \& Lewis, S. M. (1991). Practical Haematology (7th ed., pp. 659-661). Chuchill Livingstone, London.

Duncan, D. B. (1955). New multiple range and multiple F-test. Biometrics, II, 1-42. http://dx.doi.org/10.2307/3001478

Falcão-e-Cunha, L., Castro-Solla, L., Maertens, L., Marounek, M., Pinheiro, V., Freire, J., \& Mourão, J. L. (2007). Alternatives to antibiotic growth promoters in rabbit feeding: A review. World Rabbit Science, 15, $127-140$.

Favarato, M., \& Zatta, P. (1990). Chemico-clinical characterisation of rabbit serum. Journal of Applied Rabbit Research, 13, 14-15.

Galip, N. (2006). Effect of supplemental yeast culture and sodium bicarbonate on ruminal fermentation and blood variables in rams. Journal of Animal Physiology and Animal Nutrition, 90, 445-452. http://dx.doi.org/10.1111/j.1439-0396.2006.00625.x

Hassan, R. A., Ebeid, T. A., Abd El-Lateif, A. I., \& Ismail, N. B. (2011). Effect of dietary betane supplementation on growth, carcass and immunity of New Zealand White rabbits under high ambient temperature. Livestock Science, 135, 103-109. http://dx.doi.org/10.1016/j.livsci.2010.06.132

Ingraham, R. H., \& Kappel, L. C. (1988). Metabolic profile testing. Veterinary Clinics of North America. Food Animal Practice, 4, 391-411.

Rodrigues, A. C. P., Nardi, R. M., Bambirra, E. A., Vieira, E. C., \& Nicoli, J. R. (1996). Effect of Saccharomyces boulardii against experimental oral infection with Salmonella typhimurium and Shigella flexneri in conventional and gnotobiotic mice. Journal of Applied Bacteriology, 81, 251-256. http://dx.doi.org/10.1111/j.1365-2672.1996.tb04325.x

Shareef, A. M., \& AL-Dabbagh, A. S. A. (2009). Effect of probiotic (Saccharomyces serevisiae) on performance of broiler chicks. Iraqi Journal of Veterinary Science, 23, 23-29.

Shehu, B. M., Ayo, J. O., Ayanwale, B. A., Jiya, E. Z., \& Tsado, D. N. (2014). Growth performance and nutrient digestibility of weaned rabbits fed diets supplemented with varying levels of baker's yeast (Saccharomyces cerevisiae). International Journal of Agriculture and Rural Development, 17(1), 1619-1627.

Stanisław, M., \& Przemysław, S. (2009). Effect of dietary supplementation with Saccharomyces cerevisiae dried yeast on milk yield, blood biochemical and haematological indices in ewes. Bulletin of the Veterinary Institute in Pulawy, 53, 753-758.

Statistical Analysis System (SAS). (2004). SAS/STAT User's Guide (9th ed.). SAS Inst. Inc., Cary NC, USA. 


\section{Copyrights}

Copyright for this article is retained by the author(s), with first publication rights granted to the journal.

This is an open-access article distributed under the terms and conditions of the Creative Commons Attribution license (http://creativecommons.org/licenses/by/3.0/). 